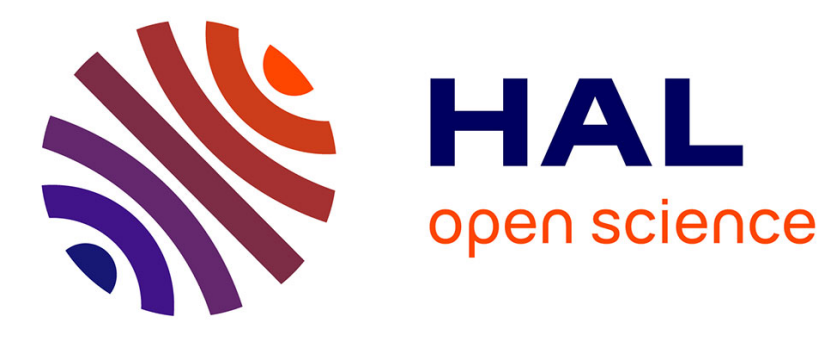

\title{
Erroneous coal maturity assessment caused by low temperature oxidation.
}

Yoann Copard, Jean-Robert Disnar, Jean-François Becq-Giraudon, Fatima

Laggoun-Défarge

\section{- To cite this version:}

Yoann Copard, Jean-Robert Disnar, Jean-François Becq-Giraudon, Fatima Laggoun-Défarge. Erroneous coal maturity assessment caused by low temperature oxidation.. International Journal of Coal Geology, 2004, 58, pp.171-180. 10.1016/j.coal.2003.10.007 · hal-00067861

\section{HAL Id: hal-00067861}

\section{https://hal-insu.archives-ouvertes.fr/hal-00067861}

Submitted on 18 May 2006

HAL is a multi-disciplinary open access archive for the deposit and dissemination of scientific research documents, whether they are published or not. The documents may come from teaching and research institutions in France or abroad, or from public or private research centers.
L'archive ouverte pluridisciplinaire HAL, est destinée au dépôt et à la diffusion de documents scientifiques de niveau recherche, publiés ou non, émanant des établissements d'enseignement et de recherche français ou étrangers, des laboratoires publics ou privés. 


\title{
Erroneous coal maturity assessment caused by low temperature oxidation
}

\author{
Y. Copard J. R. Disnar, J. F. Becq-Giraudon and F. Laggoun-Défarge \\ ISTO-UMR 6113 du CNRS, bâtiment Géosciences, Université d'Orléans, rue de \\ St. Amand, BP 6759, 45067, Orléans cedex 2, France
}

\section{Abstract}

Previous work carried out on different outcrop coals from the French Massif Central revealed abnormally high $T_{\max }$ values, which initially were attributed to high temperature oxidising fluids. This increase in $T_{\max }$, which was exclusively observed for medium to low volatile bituminous coals ( $R_{r} \geq 1.5 \%$ ), was accompanied by a very clear exponential-like decrease of the hydrogen index (HI) together with an increase in the oxygen index (OI). With the aim of checking the possibility that this rise in $T_{\max }$ could simply be caused by weathering, a few mature coal samples $\left(R_{r}>1.4 \%\right)$ were experimentally oxidised at rather low temperatures $\left(110,125\right.$ and $150{ }^{\circ} \mathrm{C}$ ) and for durations of up to 6.5 month. Then the oxidation residues were subjected to Rock-Eval 6 pyrolysis and to vitrinite reflectance measurements. These experiments effectively reproduce the geochemical changes displayed by the naturally altered coals, thus supporting the hypothesis that the previously studied natural alteration process could have been ultimately caused by weathering. The observed artificial oxidation path could be divided into two stages: (i) a strong decrease in HI and an increase in $O I$ and (ii) a constant HI value and a slow rise in OI. The increase in $T_{\max }$ seems related to the transition between the first and the second stages. This behaviour of HI and OI during artificial oxidation suggests that these two Rock-Eval derived indices can be practically used to detect a moderate and even a low oxidation degree. Finally, if one ignores the constancy of the vitrinite reflectance values all along the oxidation path, the decrease of $H I$ and the concomitant increase of $T_{\max }$ mimic a thermal evolution pathway.

Author Keywords: Vitrinite reflectance; Rock-Eval; Artificial oxidation; Humic coal; Coal rank 


\section{Introduction}

Recently, the analysis of outcrop coals collected in various Carboniferous basins of the French Massif Central, led us to envisage that these mature coals $\left(R_{r}>1.5 \%\right)$ had been affected by warm and oxidising fluids (Copard et al., 2000). This explanation was mostly based on the disagreement between vitrinite reflectance $\left(R_{r \sim} 1.5 \%\right)$ and $T_{\max }$ values derived from Rock-Eval pyrolysis ( $>550$ ${ }^{\circ} C$ ). These conflicting maturity parameters resulted in uncertainty with regard to the maturity level effectively reached by these coals. Indeed, while their $\% R_{r}$ values reflected burial diagenesis, the altered coals were characterised by abnormally high $T_{\max }$ values and low hydrogen index (HI) values (expressed in $\mathrm{mg}$ HC $g^{-1}$ TOC), frequently accompanied by high oxygen index (OI) values (expressed in $\mathrm{mg} \mathrm{O}_{2} \cdot \mathrm{g} \mathrm{TOC}{ }^{-1}$ ). Since other independent work on less mature coals $\left(R_{r} \sim 0.8 \%\right)$ did not show any variation of $T_{\max }$ during weathering (Lo and Cardott, 1995), such an option was excluded for these altered highly mature samples despite the fact that they had been collected at outcrop.

Nevertheless, a further analysis of our data in a $R_{r} / T_{\max }$ diagram (Fig. 1) reveals that, except for two samples, the $T_{\max }$ anomaly observed for highly mature coals does not affect slightly mature ones taken from a neighbouring area. Thus, consistently with the independent work of Lo and Cardott (1995), these slightly mature samples ( $R_{r} \sim 0.6 \%$; Fig. 2) were supposedly solely weathered as suggested by the decrease in HI values together with the increase in OI values, without any $T_{\max }$ variation. An additional possibility suggested by these observations is that, for highly mature coals, weathering could be responsible for increasing $T_{\max }$ (as is the case for OI while HI decreases).

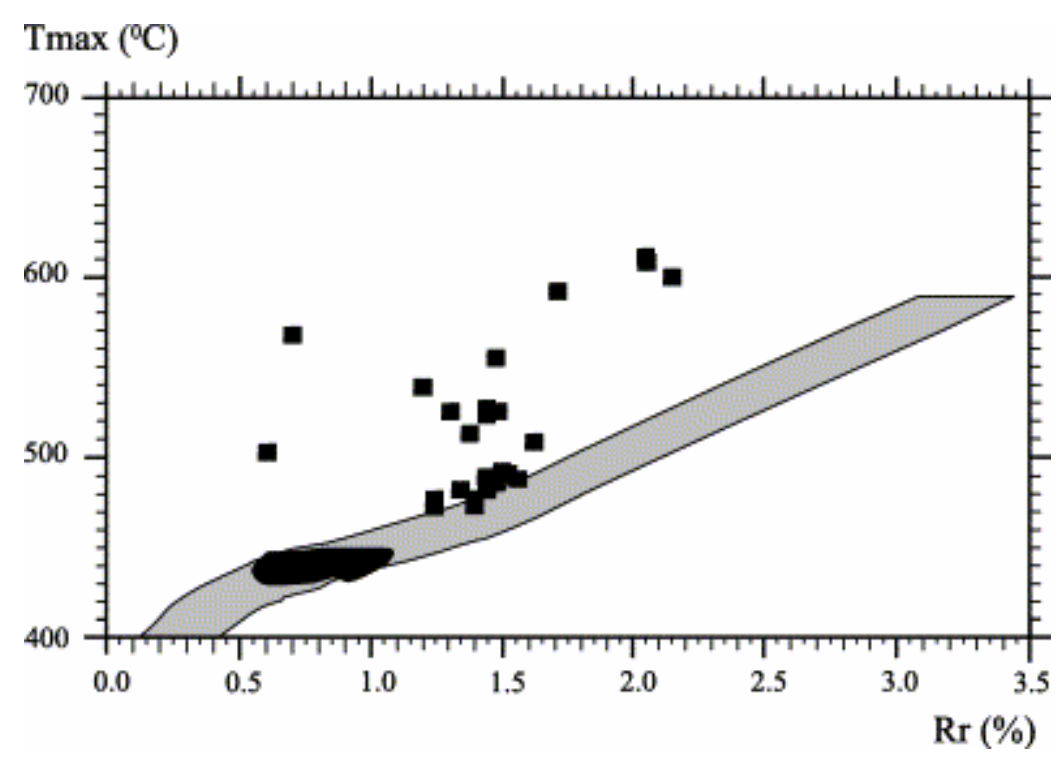

Fig. 1. $R_{r} / T_{\max }$ diagram (after Copard et al., 2000). The grey area corresponds to the $R_{r} / T_{\max }$ correlation of Teichmüller and Durand (1983). 


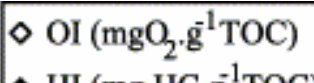

HI (mg HC. $\left.\mathrm{g}^{-1} \mathrm{TOC}\right)$

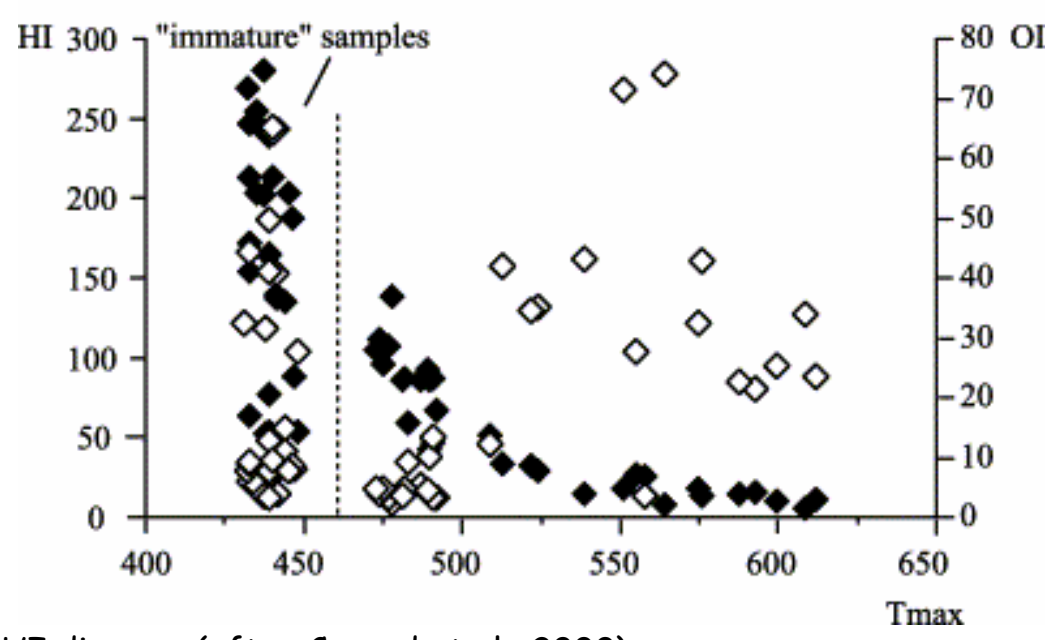

Fig. 2. $T_{\max } / O I / H I$ diagram (after Copard et al., 2000).

To check this possibility, a non-altered mature coal has been oxidised at different temperatures for a given duration. Additionally, four coal samples representing different oxidation states were artificially oxidised at $110{ }^{\circ} \mathrm{C}$ to follow the evolution of the amounts of oxygen and hydrogen, respectively, fixed and released, during the oxidation experiments. Then, the experimental data were compared to those from the previous field study (Copard et al., 2000).

\section{Characteristics of samples and methods}

Two of humic coal samples were collected at outcrop in the Saint-Etienne and Graissessac coalfields, France. The Saint-Etienne samples (G51 and G42) were taken from two immediately superimposed seams (Fig. 3a) whereas samples (Se42 and Se43) from Graissessac were taken from the same seam but on either side of a dirt band (Fig. 3 b). According to the data presented in Table 1 , the reflectance values of $\mathrm{Se} 42$ and 651 , which are in agreement with their respective $T_{\max }$ values (as well as with their $H I$ and $O I$ values), are indicative of a rank of medium and low volatile bituminous coals, respectively. Sample $G 42$ exhibits the same characteristics as those exhibited by coals which have been supposedly oxidised by hot and oxidising fluids, namely a higher $T_{\max }$ than expected considering its vitrinite reflectance value $\left(>550^{\circ} \mathrm{C}\right.$ vs. $1.5 \% R_{r}$; Copard et al., 2000). Based on its geochemical characteristics, Se43 is at an intermediate alteration stage, between the unaltered coal samples G51 and Se42 and the anomalous sample G42. These four samples exhibit a homogeneous maceral composition, largely dominated by vitrinites ( $>85 \%)$. The remainder is composed of inertinites, non-fluorescent liptinites, and minerals (clays and quartz). 

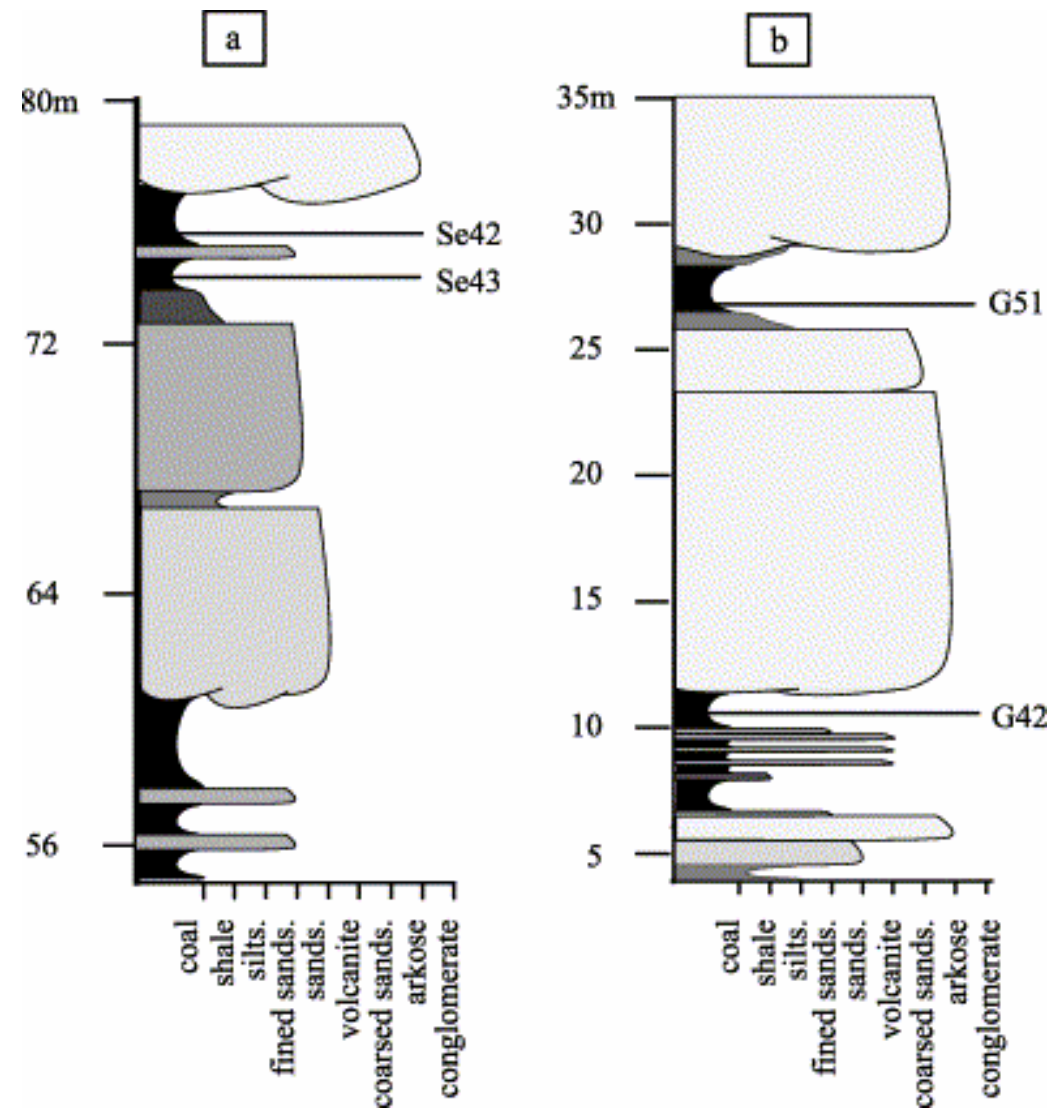

Fig. 3. Stratigraphic location of the examined samples. (a) $G 51$ unaltered sample and its oxidised homologous G42 sample (St Etienne). (b) Se42 unaltered sample and its slightly oxidised counterpart Se43 (Graissessac).

\begin{tabular}{lllclc}
\hline Sample & $\begin{array}{l}R_{r} \\
(\%)\end{array}$ & $\begin{array}{l}T_{\max } \\
\left({ }^{\circ} \mathrm{C}\right)\end{array}$ & $\begin{array}{l}\mathrm{HI}(\mathrm{mg} \\
\mathrm{HC} \mathrm{g}^{-1} \\
\mathrm{TOC})\end{array}$ & $\begin{array}{l}\text { TOC } \\
(\%)\end{array}$ & $\begin{array}{l}\text { OI (mg } \\
\mathrm{O}_{2} \mathrm{~g} \mathrm{~g}^{-1} \\
\text { TOC) }\end{array}$ \\
\hline G51 & 1.51 & 490 & 87 & 75 & 4 \\
G42 & 1.46 & 575 & 17 & 57 & 32 \\
Se42 & 1.40 & 474 & 112 & 29 & 4 \\
Se43 & 1.46 & 490 & 43 & 40 & 10 \\
\hline
\end{tabular}

Table 1. RE6 parameters and reflectance of raw samples

The initially non-altered coal $G 51$ was oxidised in a ventilated drying oven at 110 , 125 and $150{ }^{\circ} \mathrm{C}$ for a duration of up to 278 days $\left(110{ }^{\circ} \mathrm{C}\right)$. Additionally, the four samples (G51, G42, Se42, Se43) were oxidised in similar conditions at a fixed temperature of $110^{\circ} \mathrm{C}$ and always for the same duration (278 days).

Rock-Eval® RE6 pyrolyses were performed on oxidised residues according to standard conditions (Lafargue et al., 1998) with a temperature program of $25^{\circ} \mathrm{C}$ $\mathrm{min}^{-1}$. Random vitrinite reflectance measurements $\left(\% R_{r}\right)$ were carried out on polished grain sections using a DMR XP Leitz microscope in reflected white light mode, using (50x) oil immersion objective, following usual ICCP procedures. 


\section{Results}

\subsection{Optical characteristics of residues}

For all samples, independent of the oxidation temperature, vitrinite reflectance values of the oxidised residues remained systematically unchanged, within the limits of measurement uncertainties (Table 2; Fig. 4). Petrographical examination of the oxidised residues did not reveal any alteration fringes and/or rims, such as those often mentioned in the literature (Alpern and Maume, 1969; Krevelen Van, 1981 and Bend and Kosloski, 1993).

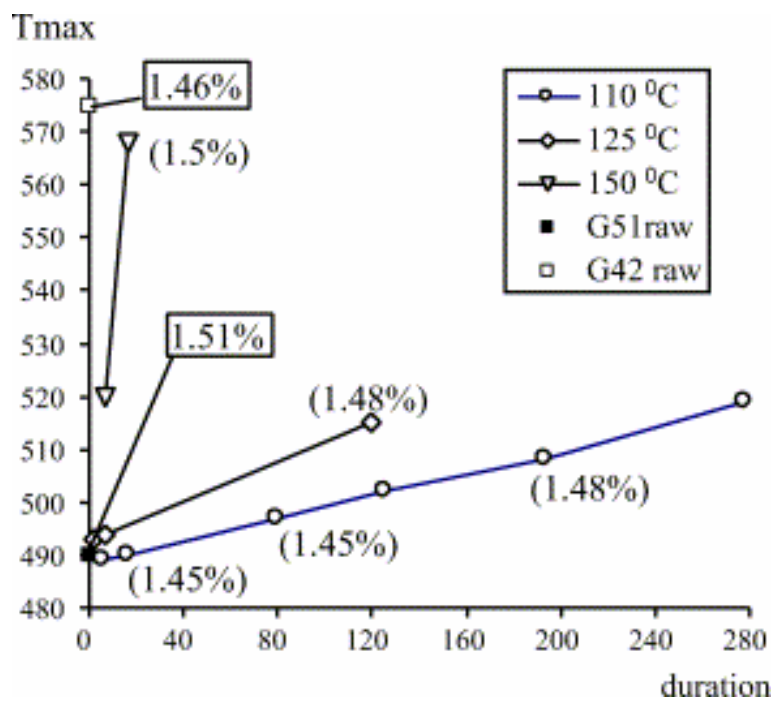

Fig. 4. $T_{\text {max }}$ /oxidation duration diagram of oxidised residues of sample $G 51$ obtained at different temperature.

\subsection{Artificial oxidation at different temperatures ( $G 51$ sample)}

The Rock-Eval data of residues obtained by artificial oxidation of the initially non-altered coal (sample G51) are given in Table 2. Systematically, HI decreases with a concurrent increase in OI, the importance of the change of both these parameters depending on the temperature and the duration of experimental oxidation (Fig. 5 and Fig. 6). $T_{\max }$ increases also noticeably with the oxidation duration but at different rates depending on the temperature (Fig. 4). For example, a similar $T_{\max }$ increase is obtained by oxidation at $110{ }^{\circ} \mathrm{C}$ for 278 days and at $125^{\circ} \mathrm{C}$ for 120 days. At higher temperature $\left(150^{\circ} \mathrm{C}\right)$, a drastic increase in $T_{\max }\left(80^{\circ} \mathrm{C}\right)$ is recorded after just over 2 weeks (17 days). 


\begin{tabular}{lrllllc}
\hline Sample & $\begin{array}{l}\text { Time } \\
\text { (days) }\end{array}$ & $\begin{array}{l}R_{q} \\
(\%)\end{array}$ & $\begin{array}{l}T_{\max } \\
\left({ }^{\circ} \mathrm{C}\right)\end{array}$ & $\begin{array}{l}\mathrm{HI}(\mathrm{mg} \\
\mathrm{HC} \mathrm{g}^{-1} \\
\text { TOC) }\end{array}$ & $\begin{array}{l}\text { TOC } \\
(\%)\end{array}$ & $\begin{array}{l}\text { OI (mg } \\
\mathrm{O}_{2} \mathrm{~g}^{-1} \\
\text { TOC) }\end{array}$ \\
\hline G51 raw & 0 & 1.51 & 490 & 87 & 75 & 4 \\
$110^{\circ} \mathrm{C}$ & 6 & n.d. & 489 & 92 & 84 & 4 \\
& 17 & 1.45 & 490 & 84 & 81 & 6 \\
& 80 & 1.45 & 497 & 64 & 82 & 8 \\
& 125 & n.d. & 502 & 62 & 82 & 10 \\
& 193 & 1.49 & 508 & 60 & 77 & 13 \\
$125{ }^{\circ} \mathrm{C}$ & 278 & n.d & 519 & 59 & 78 & 15 \\
& 2 & 1.5 & 493 & 87 & 87 & 6 \\
$150{ }^{\circ} \mathrm{C}$ & 7 & 1.51 & 494 & 69 & 86 & 10 \\
& 120 & 1.48 & 515 & 36 & 82 & 24 \\
& 7 & n.d. & 520 & 38 & 71 & 19 \\
\hline
\end{tabular}

Table 2. RE6 parameters and reflectance of raw and oxidised products of $G 51$ unaltered coal at different temperatures

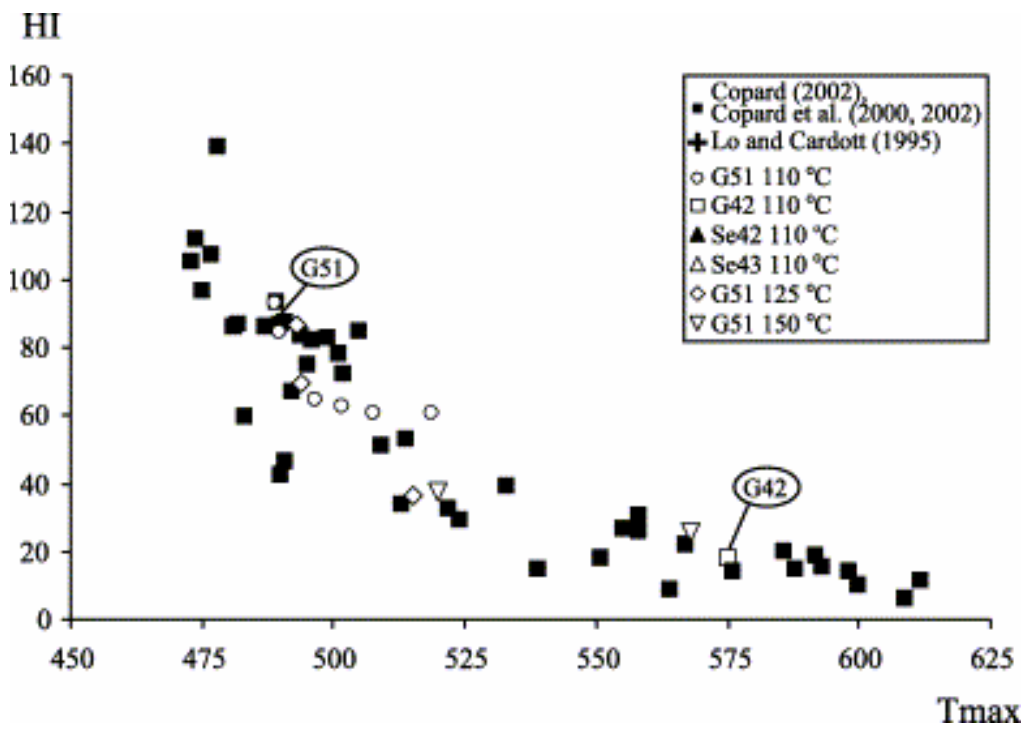

Fig. 5. $T_{\text {max }} / H I$ diagram of $G 51$ oxidised residues at different temperatures.

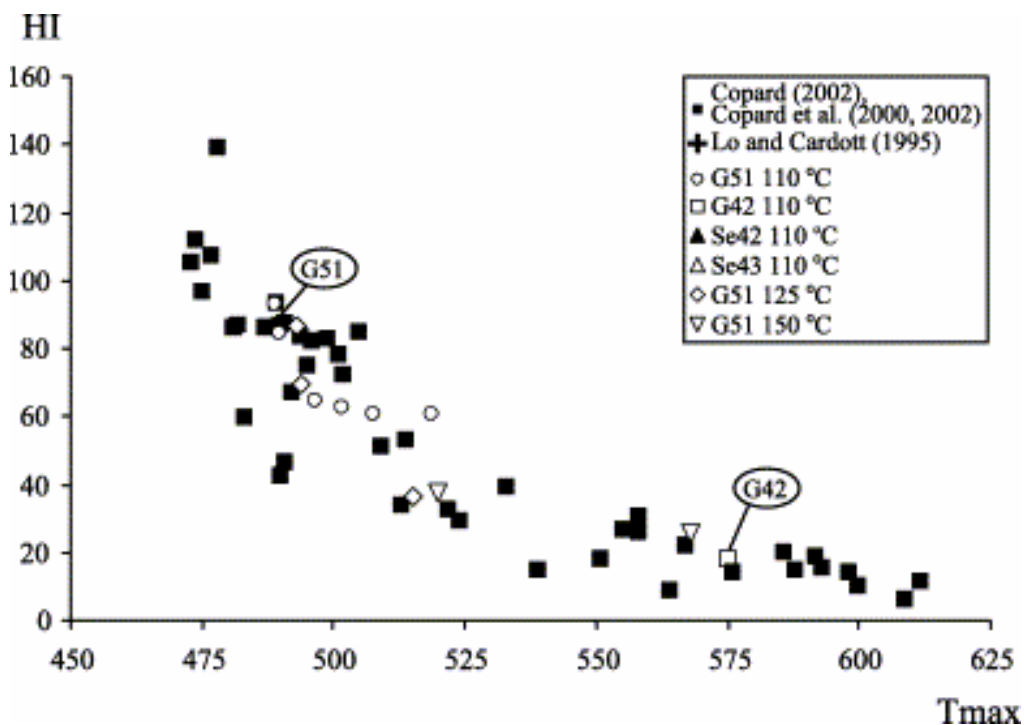

Fig. 5. $T_{\max } / H I$ diagram of $G 51$ oxidised residues at different temperatures. 


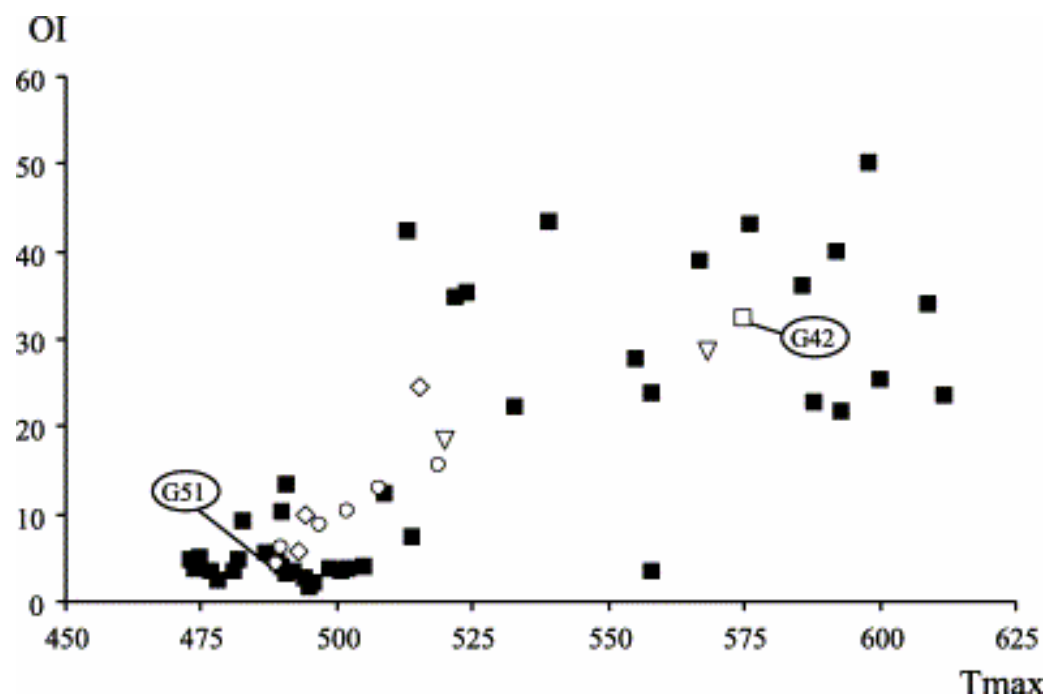

Fig. 6. $T_{\max }$ OI diagram of G51 oxidised residues at different temperatures (legend: see Fig. 5).

\subsection{Artificial oxidation at $110^{\circ} \mathrm{C}$ (all samples)}

For sample G42, when examined in a HI vs. OI diagram, the oxidation process appears to proceed following two successive stages delimited by a slope breakdown (Fig. 7). The first stage is characterised by a decrease in HI conjointly with an increase in OI. Its duration varies depending on the amount of pyrolysable hydrogen of the samples. For example, the first stage lasts 90 days for Se42 $\left(H I_{0}=112 \mathrm{mg} \mathrm{HC} g^{-1}\right.$ TOC) but only 17 for Se $43\left(\mathrm{HI}_{0}=43 \mathrm{mg} \mathrm{HC} \mathrm{g}^{-1}\right.$ TOC). The second stage is mostly characterised by a slow increase of OI and relatively constant HI values, i.e. $50 \mathrm{mg} \mathrm{HC} \mathrm{g}^{-1}$ TOC for $G 51$ and Se42 samples, and between 30 and $40 \mathrm{mg} \mathrm{HC} \mathrm{g}^{-1} \mathrm{TOC}$ for the Se43 sample. In contrast, for the initially strongly oxidised sample 642, the absence of any decrease in HI indicates that it had likely already naturally reached the second and last oxidation stage depicted in Fig. 7. Except for G42, a progressive increase in $T_{\max }$ values, which commonly corresponds to an increase of thermostability of organic matter (Espitalie et al., 1985 and Disnar, 1994), is recorded for all samples but only after a precise duration of oxidation (see Discussion). For the initially most oxidised sample, i.e. G42, $T_{\max }$ variations are directly linked to the $S 2$ peak form, or more explicitly its flattening. 


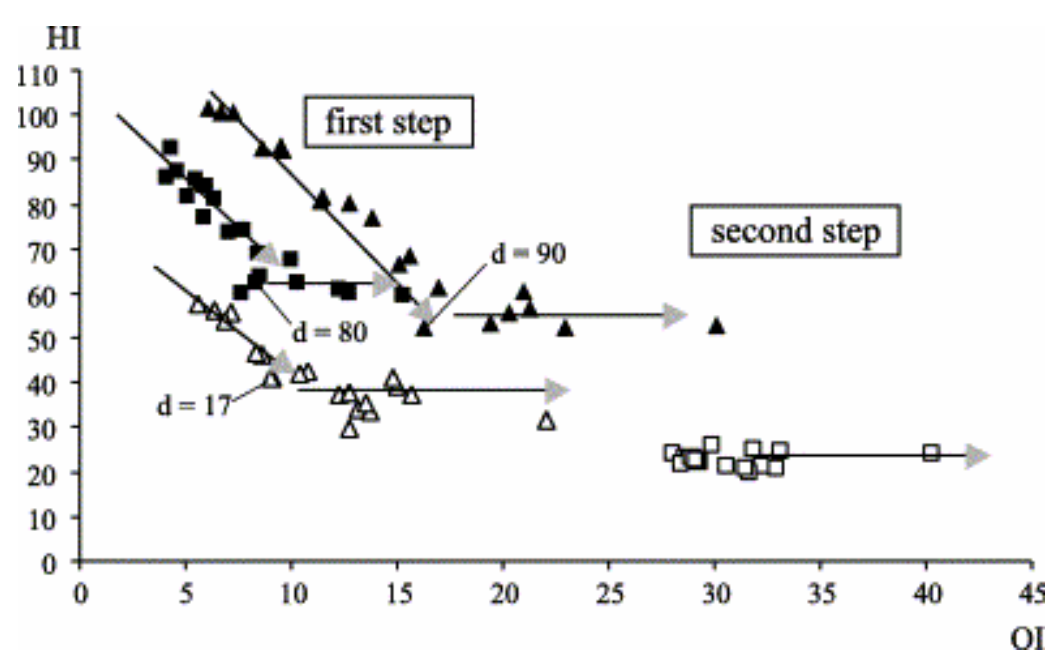

Fig. 7. diagram showing the pathway of $\mathrm{HI}$ and $\mathrm{OI}$ of the oxidised residues at $110{ }^{\circ} \mathrm{C}$ of the samples G51, G52, Se42 and Se43 (symbols: see Fig. 5).

\section{Discussion}

\subsection{Behaviour of unaltered coal during artificial oxidation at different temperatures}

The results presented in Fig. 4 show that contrary to $T_{\max }$ from Rock-Eval pyrolysis, the vitrinite reflectance appears to be unaffected by the temperature and/or the duration of artificial oxidation. In fact, this latter parameter exhibits values similar to those displayed by the raw samples. Furthermore, and even for the most oxidised residues, the absence of classical petrographic marks of oxidation such as rims and fringes suggests a moderate degree of oxidation (Kruszewska and Du Cann, 1996). This low degree of oxidation is also shown by the low OI values of these oxidised residues; the OI values are lower than those of the naturally weathered sample $G 42$ in which typical cracks and rims have been previously described (Copard, 2002).

Obviously, changes in HI and OI values could indicate a classical oxidative alteration as mentioned in various earlier studies (Landais et al., 1984; Hao and Chen, 1992; Landais and Rochdi, 1993 and Lo and Cardott, 1995). However, contrary to independent work concerning the weathering of low mature samples (Lo and Cardott, 1995), which exhibit no significant variation of $T_{\max }$, a linear increase of this parameter with respect to oxidation duration is clearly defined at $110^{\circ} \mathrm{C}$. In addition, the rise of $T_{\max }$ is most probably kinetically controlled as suggested by the different slopes shown in Fig. 4 . Hence, this increase in $T_{\max }-$ with the concurrent decrease in HI-could lead to an overestimation of the thermal maturity or level of coalification. For example, an apparent increase in maturity is observed from the raw feedstock sample ( $T_{\max }=490{ }^{\circ} \mathrm{C}$; low volatile bituminous) to the sample oxidised at $150{ }^{\circ} \mathrm{C}$ ( $T_{\max }=568{ }^{\circ} \mathrm{C}$; semi-anthracite), without any accompanying increase in vitrinite reflectance. 
The constancy of the reflectance values of all the studied samples during the experiments clearly indicates that they did not experience any artificial maturation consequential to heating. The rationale for such stability is mostly to be found in the fundamentals of organic matter diagenesis in general, and of vitrinite evolution in particular. Considering the fact that vitrinite reflectance is mainly dependent on the maximum temperature recorded by the corresponding sample (e.g. Barker and Pawlewicz, 1994) and secondarily by heating duration, the maximum experimental temperature applied to one of our samples was lower $\left(150{ }^{\circ} \mathrm{C}\right.$; sample $\left.\mathrm{G51}\right)$ than that recorded by the same sample during diagenesis (ca. $170{ }^{\circ} \mathrm{C}$; Copard, 2002). Combined with the very short duration of the experiment compared to the resident time of sedimentary formations at a given temperature during basin evolution, it can easily be assessed that the studied samples did not record any thermal maturation, even in the most severe experimental conditions (i.e. $150{ }^{\circ} \mathrm{C}$ ). Thus, the observed rise of $T_{\max }$ is only attributable to an oxidation process.

The comparison between the naturally altered sample (G42) and residues from artificial oxidation at $150{ }^{\circ} \mathrm{C}$ of unaltered sample $G 51$ reveals close similarities: (i) abnormally high $T_{\max }$ values associated with (ii) high OI and low $H I$ values, without (iii) any significant increase in vitrinite reflectance. We can thus hypothesise that a strict oxidation of mature coals at low temperature (comparable to weathering) could cause an increase in $T_{\max }$. This interpretation contradicts a previous assumption on the considered alteration of mature coals by an oxidative and warm process (Fig. 1). This new hypothesis is also reinforced by recent data showing the increase of $T_{\max }$ of mature coal samples taken at outcrop in the same deepening seam but at decreasing distance from the surface and thus with increasing weathering intensity (Copard et al., 2002). This increase in $T_{\max }$ towards the surface was accompanied by a decrease in HI and a decrease in OI, while vitrinite reflectance remained constant. The artificial oxidation experiment, together with our recent observations on outcrop coals reported above, demonstrate typical post-diagenetic oxidation (Copard et al., 2000 and Copard et al., 2002), which is distinct from an early diagenetic oxidation (Hao and Chen, 1992). The major difference between these two processes seems to lie in the vitrinite reflectance behaviour. In the case of early diagenetic oxidation, the vitrinite reflectance increases and depicts the same maturity evolution than $T_{\max }$ during burial ( $\mathrm{HaO}$ and Chen, 1992), thus entailing the same overestimation of coal rank by both of these two maturity parameters. In the case of post-diagenetic oxidation typically caused by weathering (Copard et al., 2000 and Copard et al., 2002), $T_{\max }$ increases but vitrinite reflectance remains constant or decreases slightly ( $<10 \%$ of its starting value) as suggested by previous studies (Alpern and Maume, 1969; Marchioni, $\underline{1983}$ and Lo and Cardott, 1995). 


\subsection{Behaviour of coals showing various oxidation states during artificial oxidation at a single temperature $\left(110^{\circ} \mathrm{C}\right)$}

It is currently accepted that oxidation, either natural or artificial, preferentially provokes a removal of aliphatic hydrogen and a gain in oxygen (Fredericks et al., 1983; Rhoads et al., 1983; Anderson and Johns, 1986 and Lo and Cardott, 1995). In agreement with this general consensus, artificial oxidation of humic and cannel coals has revealed, firstly a drastic, then a moderate, decrease of HI values (Landais and Rochdi, 1993), which is fully in accordance with the oxidation path observed in this study. Furthermore, since it is well known that $H I$ and $O I$ are related to $H / C$ and $O / C$ ratios, respectively, the relationship between these different parameters implies that the two depicted oxidation stages could be compared to those previously described by Joseph and Oberlin (1983) for the artificial oxidation of various organic materials. Thus, the first stage here described for the less oxidised samples corresponds to the second stage of Joseph and Oberlin (1983). The observed decrease of $H I$ could be explained by the preferential removal of aliphatic hydrogen by oxidation reactions, accompanied, among other transformations, by some reticulation reactions (Joseph and Oberlin, 1983). As indicated in Fig. 7 , the second stage is reached all the faster than the raw feedstock coal which is poor in hydrogen, or more explicitly that it has already reached a high rank. This assessment also appears to be in good agreement with the results of previous artificial oxidation experiments (Joseph, 1982).

For a residence time of up to 278 days, the relative constancy of the OI values (remaining between 28 and $33 \mathrm{mg} \mathrm{O}_{2} \mathrm{~g}^{-1}$ TOC; Fig. 7), for residues obtained from the initially oxidised sample 642 suggests that the coal did not have the capacity to capture new oxygen. This may indicate that the oxygen-bearing capacity of this coal was already reached, i.e. 'oxygen saturated'. The same remark could be made for HI, which remains constant during artificial oxidation, thus suggesting that it corresponds to little or non-reactive hydrogen.

If one excludes experimental uncertainties on $T_{\max }$ values (to within a few degrees, depending on the shape of $S_{2}$ curves), it could be possible to relate the increase of this parameter to one of the two stages defined during the artificial oxidation. Particularly, a slight jump of $T_{\max }$ occurs in the vicinity of the transition from the first to the second stage which occurs after 80, 90 and 17 days of oxidation for samples G51, Se42 and Se43, respectively. Subsequently, and excluding the last sampling of the oxidised residues Se 42 and Se 43, the "thermostabilisation" process of the organic matter in the coals resulting from the oxidation, is progressively attained as revealed by the monotonous increase in $T_{\max }$ values (Table 3 ). This relation between oxidation and the rise in $T_{\max }$ may 
easily explain why previous work almost exclusively devoted to high volatile $A$ to $C$ bituminous coals-defined by initially high $H I$ values and by a long first stage in the oxidation pathway-never noticed such increase of $T_{\max }$ during weathering (Lo and Cardott, 1995). Here again, the unchanged values of vitrinite reflectance and the increase in $T_{\max }$ values of the oxidised mature coals show a discrepancy with respect to the thermal maturity-coalification level. Finally, during natural and artificial oxidation processes, the behaviour of Rock-Eval parameters (HI, $O I$ and $T_{\max }$ ) of mature coals can simulate a classic thermal degradation pathway (Fig. 8 and Fig. 9).

\begin{tabular}{lcll}
$T_{\max }$ and reflectance of oxidised products at $110{ }^{\circ} \mathrm{C}$ & \\
\hline Sample & Time & $R_{r}$ & $T_{\max }$ \\
& (days) & $(\%)$ & $\left({ }^{\circ} \mathrm{C}\right)$ \\
\hline G51 & 6 & n.d. & 489 \\
& 17 & 1.45 & 490 \\
& 80 & 1.45 & 497 \\
& 125 & n.d. & 502 \\
& 193 & 1.49 & 508 \\
G42 & 278 & n.d & 519 \\
& 6 & n.d. & 563 \\
& 17 & 1.43 & 551 \\
& 80 & 1.43 & 566 \\
& 125 & n.d. & 559 \\
Se42 & 193 & 1.47 & 565 \\
& 278 & n.d & 559 \\
6 & n.d. & 475 \\
& 17 & 1.40 & 482 \\
& 80 & 1.44 & 485 \\
& 125 & n.d. & 501 \\
& 193 & 1.42 & 519 \\
Se43 & 278 & n.d & 547 \\
& 6 & n.d. & 487 \\
& 17 & 1.43 & 499 \\
& 80 & 1.47 & 510 \\
& 125 & n.d. & 508 \\
& 193 & 1.44 & 514 \\
& 278 & n.d & 554 \\
\hline
\end{tabular}

Table 3. $T_{\max }$ and reflectance of oxidised products at $110^{\circ} \mathrm{C}$ 


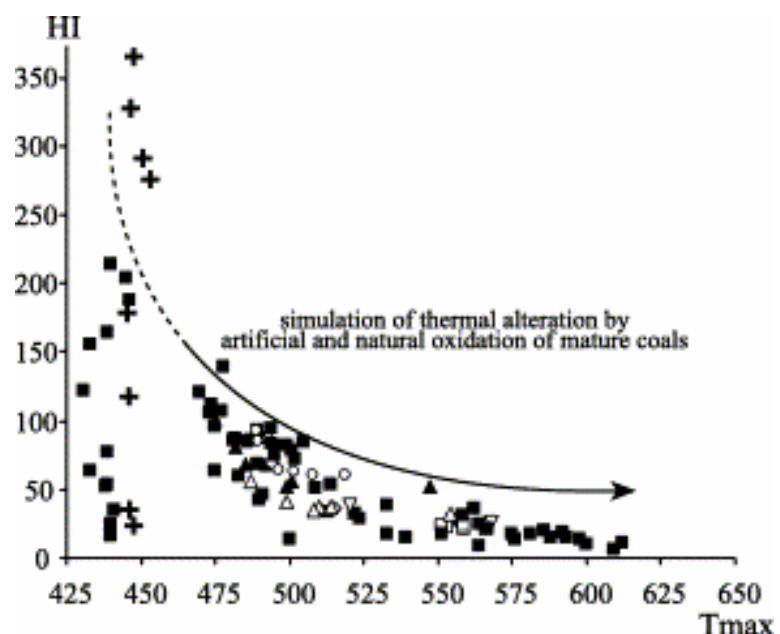

Fig. 8. $T_{\max } / H I$ diagram of all oxidised residues and a profile of weathered coals examined by Lo and Cardott (1995) (symbols: see Fig. 5).

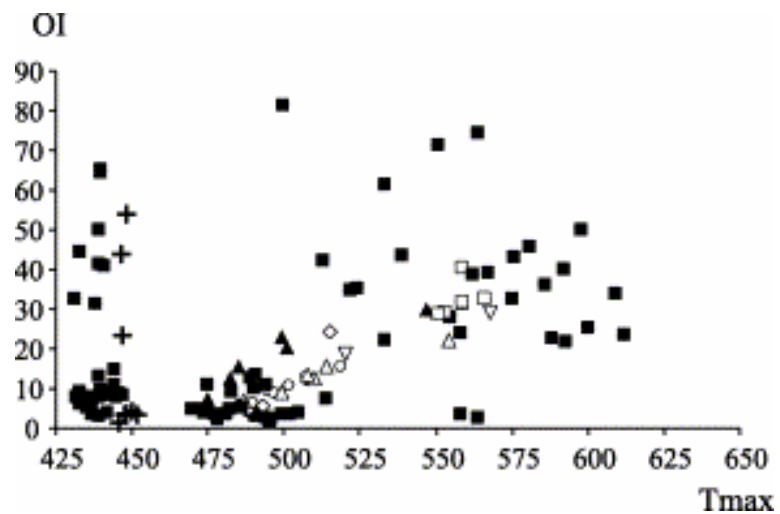

Fig. 9. $T_{\max }$ /OI diagram of all oxidised residues and a profile of weathered coals examined by Lo and Cardott (1995) (symbols: see Fig. 5).

\section{Conclusions}

As shown by the behaviour of all the studied parameters, low temperature artificial oxidation of mature coals (low volatile bituminous) reproduces the natural oxidation process. Considering that the experiments have been carried out at lower temperatures than those recorded by the coal samples during burial diagenesis (Barker and Pawlewicz, 1994 and Copard, 2002), the observed increase in $T_{\max }$ must be seen as a strict response to oxidation. The higher the experimental oxidation temperature, the greater the rate of $T_{\max }$ increase. In such a case, $T_{\max }$ can be considered as a marker of oxidation intensity but not as a rank parameter. Vitrinite reflectance does not record significant changes: even after notable weathering, it is still liable maturity indicator. 
The two stages distinguished in the oxidation path depicted by the HI and OI values could be related to those previously recognised by Joseph and Oberlin (1983) during the study of the oxidation process of various organic materials.

The evolution of the studied parameters, similar to those previously observed for a whole set of field samples supposed altered by a warm and oxidative process (Copard et al., 2000), suggests that these coals were solely weathered.

This study also illustrates the ability of RE6 parameters (HI and OI) to follow the oxidation pathways of the organic material, and can be considered as practical oxidation indicators even for a slight oxidation state.

The close relationship between the evolution of $T_{\max }$ and $H I$ mimics a thermal alteration should harbour some very strong reservations for studies concerning post-diagenetic organic matter-rich samples taken at outcrop.

\section{Acknowledgements}

This work is financially supported by the CNRS and ANDRA through the GdR FORPRO (research action number 98.IV) and corresponds to the GDR FORPRO contribution number 2003/05 A. We also acknowledge H.I. Petersen and W. Pickel for their constructive comments.

\section{References}

Alpern, B. and Maume, F., 1969. Etude pétrographique de l'oxydation naturelle et artificielle des houilles. Rev. Ind. Minér. 51, pp. 979-998.

Anderson, K.B. and Johns, R.B., 1986. Oxidation studies of Australian coals-I. Aliphatic and aromatic hydrocarbon centres of oxidative attack. Org. Geochem. 9, pp. 219-224. Abstract

Barker, C.E. and Pawlewicz, M.J., 1994. Calculation of vitrinite reflectance from thermal histories and peak temperatures. In: Mukhopadhyay, P.K. and Dow, W.G., Editors, 1994. Vitrinite Reflectance as a Maturity Parameter, Applications and LimitationsA.C.S Symposium Series vol. 570, pp. 216-229.

Bend, S.L. and Kosloski, D.M., 1993. A petrographic examination of coal oxidation. Int. J. Coal Geol. 24, pp. 233-243. Abstract

Copard, Y., 2002. Altération diagénétique et post diagénétique (thermicité, oxydation) des charbons carbonifères du Massif Central français (Saint-Etienne, Graissessac et autres lieux). PhD Thesis, Univ. Orléans, France. 
Copard, Y., Disnar, J.R., Becq-Giraudon, J.F. and Boussafir, M., 2000. Evidence and effects of fluid circulation on organic matter in intramontane coalfields (Massif Central, France). Int. J. Coal Geol. 44, pp. 49-68. SummaryPlus I Full $\underline{\text { Text }+ \text { Links I PDF (910 K) }}$

Copard, Y., Disnar, J.R. and Becq-Giraudon, J.F., 2002. Erroneous maturity assessment given by Rock-Eval parameters ( $\max$ and HI) on highly mature weathered coals. Int. J. Coal Geol. 49, pp. 57-65. SummaryPlus | Full Text + Links | PDF (551 K)

Disnar, J.R., 1994. Determination of maximum paleotemperatures of burial (MPTB) of sedimentary rocks from pyrolysis data on the associated organic matter: basic principles and practical application. Chem. Geol. 118, pp. 289-299. Abstract

Espitalié, J., Deroo, G., Marquis, F., 1985. La pyrolyse Rock-Eval et ses applications. Rev. Inst. Fr, Pet. 40 (5), 563-579, 40 (6), 755-784, 41 (1), 73-89

Fredericks, P.M., Warbrooke, P. and Wilson, M.A., 1983. Chemical changes during natural oxidation of a high volatile bituminous coal. Org. Geochem. 5, pp. 89-97. Abstract

Hao, F. and Chen, J., 1992. The cause and mechanism of vitrinite reflectance anomalies. J. Pet. Geol. 15, pp. 419-434.

Joseph, D., 1982. L'oxydation des matières carbonées, PhD thesis, Univ. Orléans, France.

Joseph, D. and Oberlin, A., 1983. Oxidation of carbonaceous matter-I. Elemental analysis $(C, H, O)$ and IR spectrometry. Carbon 21, pp. 559-564. Abstract

Krevelen Van, D.W., 1981. Coal, Typology-Chemistry-Physics-Constitution. (2nd ed.), Coal Science Technology vol. 3, Elsevier, Amsterdam 514 pp. .

Kruszewska, K.J. and Du Cann, V.M., 1996. Detection of the incipient oxidation of coal by petrographic techniques. Fuel 75, pp. 769-774. SummaryPlus I Full Text + Links I PDF (441 K)

Lafarque, E., Marquis, F. and Pillot, D., 1998. Rock-Eval 6 applications in hydrocarbon exploration, production, and soil contamination studies. Rev. Inst. Fr. Pet. 53, pp. 421-437. Abstract-Compendex 
Landais, P. and Rochdi, A., 1993. In situ examination of coal macerals oxidation by micro-FT-i.r. spectroscopy. Fue/72, pp. 1393-1401. Abstract

Landais, P., Monthioux, M. and Meunier, J.D., 1984. Importance of the oxidation/maturation pair in the evolution of humic coals. Org. Geochem. 7, pp. 249-260. Abstract-Compendex

Lo, H.B. and Cardott, B.J., 1995. Detection of natural weathering of Upper McAlester and Woodford shale, Oklahoma, USA. Org. Geochem. 22, pp. 73-83. Abstract | Abstract + References | PDF (723 K)

Marchioni, D.L., 1983. The detection of weathering in coal by petrographic, rheologic and chemical methods. Int. J. Coal Geol. 2, pp. 231-259. Abstract

Rhoads, C.A., Senftle, J.T., Coleman, M.M., Davis, A. and Painter, P.C., 1983. Further studies of coal oxidation. Fuel62, pp. 1387-1392. Abstract

Teichmüller, M. and Durand, B., 1983. Fluorescence microscopical rank studies on liptinites and vitrinites in peak and coals, and comparison with results of the Rock-Eval pyrolysis. Int. J. Coal Geol. 2, pp. 197-230. Abstract 